\title{
Social Security Privatisation in the UK: a means to whose end?
}

\author{
Daniel Edmiston* \\ University of Leeds
}

\begin{abstract}
This paper investigates how privatisation trends have affected the right to social security in the UK since 1979. Privatisation has regularly been posited as a solution to more efficiently and effectively target public services. However, the procedural effects of social security privatisation have been the opposite, with increased social spending accompanied by poorly targeted provision. Those able to wield democratic influence and consumer interests over legislative entitlement have disproportionately benefited from increased social security efforts. This paper illustrates that a confluence of factors affect the right to social security within and beyond substantive privatisation processes. Whilst the, albeit gradual, diversification of social security has proven critical, the principles underpinning such developments have proven far more significant in informing and threatening the right to social security for those who most need it.
\end{abstract}

Keywords: social rights, poverty, social security, welfare pluralism, privatisation.

\section{Introduction}

Since 1979, successive UK political administrations have remained steadfast in their commitment to diversify the funding, provision and regulation of public services. As a result, welfare pluralism has become an increasingly prominent feature of UK social policy (Hills, 2011). In both public and academic discourse, this process is often labelled 'privatisation' and is considered synonymous with welfare withdrawal (Beresford and Croft, 1983; Gamble, 1992; Self, 2000; Hutton, 2011). However, to characterise this process as a linear transition from public to private welfare, obscures the multidimensional nature of welfare pluralism. Much of the existing analysis still rests on a binary distinction between private and public welfare (e.g. Dorfman and Harel, 2013). Walker (1984) concedes that his own analysis is 'based on a comparison between the two extremes of the formal services continuum' (Walker, 1984: 34). Some have resigned themselves to 'set aside the essentially uncertain predictions about the consequences of privatisation and to refocus the debate on the real political and theoretical disagreements at issue' (Dilley, 2000: 982). Whilst a necessary step in understanding the effects of privatisation, this renders the privatisation debate empirically impoverished and does little to engage with the actualities of welfare pluralism and its effect on social rights. 
Rather than a linear transition from the State to the Market, 'varieties of privatisation and marketisation' (Clarke, 2004) have altered the welfare landscape alongside increased public social expenditure (Burchardt, 2013). Some have suggested that the term 'privatisation' is in itself problematic and does little to explain the diversity and complexity of welfare pluralism (Murphy et al., 1998; Drakeford and Campling, 2000; Powell and Miller, 2014). New public management prevails within certain policy domains and has increased state activity in certain instances through quasi-marketisation, targets and increased regulation (Banks, 2011). This paper then uses the term 'privatisation' to refer to a multiplicity of processes involved in the mixed economy of social security: the contracting-out of services; the marketisation of social insurance; the commercialisation of administrative discretion; payment by results; and so on. Making the theoretically defined phenomenon of welfare pluralism empirically tractable then is the most significant challenge to understanding the effects of privatisation.

This paper comes at a particularly important conjuncture when a renewed zeal for privatisation has taken hold in the UK. A fresh round of public sector reform is underway against the backdrop of fiscal austerity (Cabinet Office, 2011). This paper explores how trends in social security privatisation have affected both the means and ends of welfare pluralism. Various studies have explored the effects of welfare pluralism on the right to healthcare and education (e.g. Pollock, 2006; Toebes, 2006; Kathleen, 2006). However, relatively little attention has been paid to privatisation processes affecting the right to social security. All domains of welfare activity have a significant bearing on social rights. However, the ability to fully exercise other social, civil and political rights is dependent on a minimum level of income (Torry, 2013). Without this, other rights become 'empty moral possessions' (Melden, 1979: 248). Social security then is the core welfare domain and the effects of privatisation processes are particularly important to understand.

There are a number of apprehensions concerning the impact of welfare pluralism on the right to social security. Many consider social security to be a public good (Dorfman and Harel, 2013: 69) that collectivises and redistributes life risks (EspingAndersen, 1990: 40-43). With the introduction of market principles and/or private actors, social security becomes susceptible to profit logics that underpin market principles. If this occurs, social security administration and provision has the capacity to become socially stratified in a way that reflects, and perhaps propagates, existing inequalities and status differentials within the polity (Blomqvist, 2004). In this instance, the function and purpose of social security is compromised with resources no longer distributed according to social or moral objectives, such as meeting human need (Titmuss, 1968). This undermines the status of social security as a public good which is, of course, contested but at its most basic, intends to shelter people against life risks so that that they are able to secure a minimum income independently of the paid labour market. Essentially, privatisation has the potential to undermine the efficacy, function and purpose of social security such that the status and justiciability of the right to social security are compromised. Some have already explored how social security privatisation processes have affected welfare outcomes (e.g. Taylor-Gooby et al., 2004). Analytical attention has been paid to particular features of social security privatisation such as pensions (e.g. Hyde et al., 2003). This paper builds upon such analysis to explore how privatisation trends in the regulation, finance and provision of social security have affected the right to social security since 1979.

The paper begins by outlining how the substantive and procedural rights to social security have to be accounted for in order to fully understand the effects of privatisation. The paper then considers how the right to social security is variously constituted through moral, political and legal means and how the substantive right to 
social security has fared since 1979 . The paper then summarises the key privatisation trends in social security involving institutional as well as individual private actors. Examining the significance of private actors in the control, funding and provision of social security, the paper then explores how the right to social security has fared in the, albeit gradual, diversification of social security. The paper then illustrates how the changing distribution of social security receipt has come to reflect the logic underpinning welfare pluralism. As such, social security privatisation in its various procedural and institutional manifestations has weakened the capacity for social security to address rising poverty and inequality. The paper concludes that a 'privatisation ethos' increases the mandate of those most able to exert consumer interests and democratic power to maximise the social security they receive.

\section{The right to social security}

Private funding, control and provision have the capacity to shape the mechanisms by which social goods are administered and in turn affect welfare outcomes. Social security primarily concerns the (re-) distribution of economic capital, but this is interpolated with a range of processes susceptible to welfare pluralism that can affect the justiciability and distributive efficacy of social security. There are differing, and often conflicting, accounts of what comprises the right to social security: 'the whole range from the right to a modicum of economic welfare and security to the right to share to the full in the social heritage and to live the life of a civilised being according to the standards prevailing in the society' (Marshall, [1950] 1992: 8). Irrespective of whether a minimalist or maximalist conception is adopted, it will encompass substantive claims to social security as well as procedural rights in the administration and disbursement of social goods (Coote, 1992; Lister, 1998). In light of this, employing one definition or 'benchmark' of the right to social security proves problematic when exploring the effects of privatisation and welfare pluralism. In order to understand the effects of this trend, it is necessary to accommodate the different ways in which social security rights are conceived, administered and realised.

The right to social security is fashioned from principles underpinning the provision and securement of welfare. This may entail a claim to welfare based on a principle of need, desert, equality and so on. This provides a moral basis from which to justify and realise the rights (and indeed, responsibilities) of citizenship. Contingent on the political paradigm in question, different principles will be drawn upon to codify claims to social security in law. The UK's ratification of the International Covenant on Economic, Social and Cultural Rights is of symbolic and material significance here and the right to social security is reflected in a range of income entitlements for different groups (European Union, 2013). At its most basic, the right to social security entails access to a minimum income from the state so that human needs are met. ${ }^{1}$ Without possession of sufficient economic capital, the substantive right to social security is compromised.

Before outlining privatisation trends since 1979, I will consider how the substantive right to social security has fared by looking at the changing prevalence of relative poverty in the UK. The proportion of people living below 60 per cent of median income (after housing costs) rose from 14 per cent in 1979 to 25 per cent in 1997 and has since fallen to 21 per cent in 2012 (Crawford et al., 2013). Despite substantial growth in social security spending, at least a fifth of the UK population has remained in relative poverty since 1987 . There are many factors explaining this trend, including weakened predistribution instruments, structural unemployment and underemployment and rising income inequality (Shildrick et al., 2012; Joyce and Sibieta, 2013; Lansley, 2014). These factors are of central importance to understanding how and why the state has failed to fulfil the right to social security for a growing proportion of the UK population. 
However, this paper focuses on policies and activities that enable citizens to secure a minimum income irrespective of their proximity to or engagement with the paid labour market. In this regard, there are three primary explanations for the prevalence of relative poverty and failure to fulfil the right to social security.

Firstly, the provision and generosity of social security has become increasingly contingent on the socio-demographic, familial and employment status of benefit claimants. Under New Labour and now the Conservative-Liberal Democrat Coalition government, social security efforts have been focused on pensioners, children and working families. From 1997 to 2012, pensioner poverty more than halved (from 29 to 14 per cent), child poverty decreased from 34 to 27 per cent and working age parent poverty decreased from 27 to 23 per cent (Crawford et al., 2013). During the same period, working age non-parents lost out with the poverty rate increasing from 17 to 20 per cent. Secondly, despite increased social expenditure, the relative value of certain benefits has fallen dramatically. Part of the explanation for this is that social security payments have struggled to keep pace with rising median incomes and the growing income share of the top ten per cent of earners (Joyce and Sibieta, 2013). Between 1979 and 2012, the value of the basic state pension fell from 26 to 17.7 per cent of average earnings and unemployment benefit/job-seeker's allowance fell from 20.6 to 11.7 per cent. Between 1988 and 2012, the value of Income Support for single people aged over 25 fell from 15.3 to 11.7 per cent of average earnings (DWP, 2013). Finally, as illustrated later in this paper, social security payments have become increasingly less effective at targeting resources according to a principle of need. All this would suggest a cumulative degradation of the financial position of those reliant on social security to fulfil their basic and fuller needs.

A trend towards welfare pluralism in the UK then is coupled with increasing poverty and state failure to enable all citizens, at least by virtue of their status, to participate according to the standards prevailing in society (Marshall, [1950] 1992). Having said that, trying to correlate social security privatisation trends with the right to a minimum income is a highly unsatisfactory account of how privatisation may be affecting the right to social security. The existing structures of social security provision (public or private) are moulded by privatisation principles. This of course has a bearing on social security outcomes and the substance of social rights, but it also has significant procedural effects of the right to a minimum income. I will now outline the key social security privatisation trends before considering their procedural effect on the right to social security.

\section{Social security privatisation: a variegated process}

This paper focuses on the 'formal' rather than the 'informal' aspects of social security. That is, the changing status of the right to a minimum income from the state rather than access to funds via clientelist kinship and support networks (Wood, 2004). As such, it is important to consider both working-age and pensioner benefits, but also the administrative structures that have a bearing on their disbursement. Acknowledging the multi-dimensional nature of privatisation, this paper examines the role and significance of private and public actors in the regulation, provision and finance of social security. Similarly to LeGrand and Robinson (1984) and Papadakis and TaylorGooby (1987), Burchardt (1997) explores the changing role of private and public actors in the control, delivery and finance of welfare activity. Burchardt's typology has been applied to four different time periods to examine who delivers, finances and controls welfare services, and also how these aspects of welfare activity coalesce to offer different combinations of welfare activity (Burchardt, 1997; Smithies, 2005; Edmiston, 2011; Hills, 2011). This paper draws on data from the most recent assessment of how 
public and private actors feature in social security activity in the UK (Edmiston, 2011). Within this typology, private actors include private organisations providing services in the administration and distribution of social security entitlements, but also individuals purchasing private welfare insurance. Both sets of private actors play a significant role in welfare pluralism and should both be included in any analysis of the effects of privatisation on the right to social security.

Reviewing the evidence, it would appear that the shifting balance of welfare activity in social security has been gradual in the period running from 1979 to 2008 (see Table 1). Total public spending on social security has decreased from 81 to 78 per cent of all spending on social security and total private spending has increased from 19 to 22 per cent. There have of course been fluctuations over the 29 year period, but overall, individual and institutional private actors now play a greater role in the domain of social security.

Table 1: Welfare Activity: Spending (£billion, 2007-08 prices RPI adjusted)

\begin{tabular}{lcccc}
\hline & $1979-80$ & $1995-96$ & $1999-00$ & $2007-08$ \\
\hline Total Social Security Spending & 113.0 & 174.4 & 179.2 & 239.3 \\
As a \% of GDP & $16.0 \%$ & $16.5 \%$ & $15.1 \%$ & $16.7 \%$ \\
Total Public Social Security Spending & 91.1 & 147.0 & 146.8 & 186.4 \\
As a \% of social security Spending & $80.6 \%$ & $84.3 \%$ & $81.9 \%$ & $77.9 \%$ \\
As a \% of GDP & $12.9 \%$ & $13.9 \%$ & $12.3 \%$ & $13.0 \%$ \\
Total Private Social Security Spending & 21.9 & 27.2 & 32.1 & 52.9 \\
As a \% of social security Spending & $19.4 \%$ & $15.6 \%$ & $17.9 \%$ & $22.1 \%$ \\
As a \% of GDP & $3.1 \%$ & $2.6 \%$ & $2.7 \%$ & $3.7 \%$ \\
\hline Source Edmiston $(2011)$
\end{tabular}

Source: Edmiston (2011)

The biggest driver of this trend is a diversification in the provision, finance and regulation of pensions. Designed to incentivise saving, state second pensions, occupational pensions and tax reliefs have had a profound effect on the welfare mix in social security. If pensions were to be excluded from social security spending, the vast majority of welfare activity would be publicly controlled, delivered and financed: 99.6 per cent in 1979-80 and 97 per cent in 2007-08 (Edmiston, 2011). In fact, the proportion of social security that remained purely public (that is, publicly controlled, delivered and financed) increased from 57 to 65 per cent between 1979-80 and 199596 and has steadily fallen since. The proportion of social security activity that was purely private fell between $1979-80$ and 1995-96 from 19 to 16 per cent, and rose to 22 per cent of welfare activity in 2007-08 (Edmiston, 2011).

Privatisation is often interpreted as a euphemism for public sector cuts (Self, 2000; Walker, 1984). In reality though, social security privatisation in the UK has been coupled with a growth in social security provision since 1979. In real terms, social security spending has increased by 111 per cent (RPI adjusted) and has increased marginally from 16 to 16.7 per cent of GDP. Public social security spending has increased marginally from 12.9 to 13 per cent of GDP and private social security spending has increased from 3.1 to 3.7 per cent of GDP during the same period. Despite a growing body of literature pronouncing the tightening grip of fiscal austerity (Cox, 1998) and permeation of neoliberal economic dogma (Self, 2000), it appears that privatisation trends have not lead to a reduction in public investment or expenditure in social security. It is therefore important to resist the idea that privatisation results in 
either, a reduction in social security spending, or, a linear transformation of public goods into private commodities. The mixed economy of welfare is exactly that - a confluence of actors controlling, delivering and financing different features of welfare activity. The following discussion then explores the procedural effects of privatisation on social security provision and services.

\section{Private provision and contracting-out}

First to be considered is the provision of social security. The most fundamental objection to privatisation is not so much the effects of it but the capacity to articulate social rights accrued from previously public services. Underpinning this argument is a belief that social goods are only 'valuable if provided by the state' (Dorfman and Harel, 2013: 69). Once social goods are provided by an actor other than the state, they lose their status as public goods. Namely, once provided by a non-state actor the right to a minimum income is mediated by factors other than moral or social imperatives (TaylorGooby et al., 2004). Private actors involved in the provision of social security potentially compromise the status of social security rights which in turn alters their substance. Whilst this may have repercussions for welfare activity that is privately financed, it is not so clear whether this is problematic for private provision in itself, or whether its fallout effects impinge more on the right to a minimum income.

Between 1979 and 2008, the proportion of social security that was privately administered fluctuated but rose marginally from 33 to 34 per cent (Edmiston, 2011). Pension provision on the other hand has diversified considerably with the proportion of pension activity delivered by private providers rising from 46 to 56 per cent during the same period. This is largely explained by a substantial growth in occupational, personal and stakeholder pensions. During the 29 year period, spending on occupational pensions increased from $£ 20.8$ billion to $£ 40$ billion. Spending on personal and stakeholder pensions increased from $£ 717$ million to $£ 10.1$ billion. In total, this private pension provision accounted for 27.1 per cent of total pension activity in 1979-80 and 35.9 per cent in 2007-08. Alongside this, expenditure on the basic state pension increased from $£ 32$ billion to $£ 49.7$ billion, but as a proportion of all pension activity, decreased from 40.2 per cent to 35.6 per cent (Edmiston, 2011). As previously stated, the real value of the basic state pension relative to average earnings has fallen substantially over time. As a result, many people are supplementing and drawing upon alternative pension provision through private means. The state has fostered such a process through a variety of tax reliefs, rebates and incentive payments which in itself accounts for a significant real-term growth in publicly funded, private pension activity. As such, the ability to secure a minimum income independent of the market has become increasingly difficult with people's pension receipt more closely reflecting their previous employment status and earnings record. To this extent, the growth in private pension provision is as much a symptom as it is a cause of the worsening right to social security upon retirement.

For those advancing an instrumental case for privatisation, contracted-out private provision enables greater flexibility, efficiency, and a more client-centred approach to service provision (NAO, 2013). Reviews of the evidence suggest that private provision 'works in that the firms become more efficient, more profitable, financially healthier, and reward investors' (Netter and Megginson, 2001: 329; Brudney et al., 2005). However, many opponents of privatisation suggest that 'contracting-out can have a depressive effect upon the quality of services without any formal breach of contract' (Self, 2000: 115). Grover (2009: 504) also illustrates how the contracting out of employment assistance services has the 'potential to reinforce, rather than alleviate labour market disadvantage'. Blomqvist (2004) suggests that private provision is problematic because it is informed by a profit logic so that access, coverage and quality 
of services becomes stratified according to existing socio-economic and political divisions: namely 'contracting out' fails to shield service users against inequalities arising from the market. As recognised by Burchardt and Hills (1997), private provision may increase efficiency i.e. value for money, but it does not increase productivity i.e. a greater fulfilment of social rights. Considine et al. (2011) found that private provision achieved neither greater efficiency nor productivity. In fact, granted the same flexibilities, public provision of services and goods is able to match, if not surpass the quality and efficiency outcomes of private providers (Davies, 2008).

In 2012-13, central and local government spent more than $£ 4.3$ billion and the Department for Work and Pensions (DWP) spent more $£ 467$ million buying goods and services from Serco, G4S, Capita and Atos (NAO, 2013). These four major contractors provide a range of goods and services that procedurally and/or substantively affect the right to social security. Taking the consultancy and professional services company Atos as an example, a significant proportion of their DWP contracts are dedicated towards work capability assessments and the eventual transition from Disability Living Allowance to Personal Independence Payments. Atos is not so much involved in the direct provision of social security in this instance, but rather in the administrative adjudication over its entitlement. Atos has come under increasing criticism for restricting the benefit entitlements of those they deem fit to work. As a private contractor, many view its treatment of disability and social security recipients as inhumane (DPAC, 2012). Prima facie, this seems to be the impact of private control and provision in welfare activity. However, this underestimates the extent to which the state is complicit in functioning according to market and/or ideological ends. Research suggests that public institutions tend to prioritise cost-savings over quality improvements when commissioning goods and services from private contractors (Brudney, 2005). DWP arrived at 'statistical norms' which translate into predefined targets to reduce the number of claimants on Employment Support Allowance and Disability Living Allowance (Franklin, 2013). As a result, Atos is compelled under contract to meet, as best as possible, such targets. Whilst, the privatisation of provision may be problematic for the right to social security, the ideological position that informs such a process may also be. By contracting out employment assistance and entitlement administration services, the state devolves part of their bureaucratic and political responsibility to contractors. To some extent, once a service is contracted out, the state is granted a level of democratic immunity from service failures. Contracting out then has the potential to procedurally affect the right to social security and limit the capacity for mechanistic and judicial redress. However, the high level of appeals against Atos decisions (DWP, 2014) illustrates how the extent of service failure and democratic immunity is not so much determined by the contractor, but by the state itself. Whether the state maintains control of service provision then, greatly determines the extent to which private provision can manipulate moral or social objectives to the logic of the market.

\section{Private control and regulation}

Between 1979 and 2008, the proportion of all social security welfare activity that was controlled by private actors fell from 42 to 38 per cent (Edmiston, 2011). In spite of increased private provision and finance in social security, the managerial state (Clarke and Newman, 1997) has maintained and extended its control in social security activity. The picture is somewhat different for pensions, with the proportion of pension activity that was privately controlled increasing from 59 to 64 per cent between 1979 and 2008 (Edmiston, 2011).

Very few, if any, core social security services and transfers are controlled by a fully autonomous system of regulation separate from public and institutional accountability. 
In a somewhat self-defeating logic, private regulation of social security can only be granted by the state, and even then the extent of control is dictated by public monitoring. Indeed, privatisation depends 'on the choices of policymakers, for example with respect to the financial conditions and legal restraints under which private actors are allowed to operate' (Blomqvist, 2004: 152-153). Frequently, it is not so much absolute private control that affects entitlement to social security; it is institutional discretion within the confines of state regulation that has the most significant impact. This is not something that is readily quantifiable. Such functions of social security are not generally captured in data on privatisation trends but importantly these discretions often result in the largest public service failures.

Looking at welfare to work services, the Work Programme can be seen as a prime example of how private discretion rather than control can affect the quality of provisions and the resultant right to social security. The Work Programme mandates certain groups to undertake work-related obligations in order to receive social security payments. In itself, this compromises the right to secure a minimum income independently of engagement or proximity to the paid labour market for some citizens. However, when targets are designed for private contractors, but a level of discretion is allowed, the right to social security is further threatened. The most recent available evaluations suggest that current providers are underperforming against contractual expectations (CESI, 2014). In addition though, evidence from initial evaluations of the Work Programme suggest that 'creaming' and 'parking' are prevalent across contractors (Newton et al., 2012). 'Creaming' occurs when those already close to the labour market are assisted into work with little investment or support required. 'Parking' occurs when those furthest away from the labour market who require greater support and assistance in moving closer to paid employment, are neglected and efforts focused on those that will generate greatest revenue for the contractor. Rees et al. (2014) conclude this is driven substantially by cost and profit pressures. Ultimately, this occurs because market objectives win out over social and policy objectives (Twine, 1994: 90). Operating according to market mechanisms is a case in point of how the quality of services and provisions are compromised by privatisation trends. Consequently, it would seem that publicly sanctioned private discretion and a lack of democratic accountability significantly determine how and who is subject to recommodification measures.

Both institutional and individual actors are involved in private decision-making in social security. Decision-making for individual actors is principally restricted to those maximising their own cash benefits, tax reliefs or incentive rebates. It may reasonably be thought that individual actors having control over these decisions doesn't substantively (or perhaps, directly) affect the right to social security. Indeed, research with those reliant on basic social security payments suggests that individual private control has little relevance to their experience of social security (Dwyer, 2000). However, this is largely explained by virtue of the fact that individual private decisionmaking in social security tends only to be an option for those with greater resources at their disposal. Again, this demonstrates how the role of private actors can adversely affect the stratification of welfare; so that transfers are distributed more according to existing capital rather than needs. This significantly affects the changing distribution of social security and is considered later in this paper. It is important to recognise here though that this has profound implications for the discursive conception of social security (Cox, 1998). By opening up the option for private actors to control, dictate and maximise their social security entitlement (primarily in the realm of pensions in this instance), social transfers are reduced to any other commodity to be bid and competed for in the market. Those with more resources at their disposal will have more control over their social security receipt which leads us to consider the role and significance of private finance in social security. 


\section{Private finance and marketisation}

By its very nature, social security collectivises and redistributes a variety of risks so that these are shared across time and the citizenry. Life course, intergenerational and class risks are all minimised by a publicly funded system of social security (EspingAndersen, 1990: 40-43). Private finance of social security then appears inherently at odds with the objectives of social security, because it individualises risk, disabling effective recourse from impoverishment for the majority subject to it. According to Richard Titmuss (1968: 129), private finance compromises the right to social security because its receipt is either stratified according to existing financial resources or its receipt is so imbued with stigma that claiming becomes prohibitive. However, differential contribution to and receipt of social security has always existed and to a great extent, is a fundamental and necessary feature of the welfare system overall.

Between 1979 and 2008, the proportion of social security that was privately financed rose from 19 to 22 per cent. Owing to occupational, personal and stakeholder pensions this figure rose from 27 to 35 per cent for pensions during the same period (Edmiston, 2011). Private financing has increased but it has not risen so significantly as to facilitate a wholesale commodification of the right to social security. For those purchasing unemployment protection insurance or private pensions, this may certainly be the case, but this could be either out of choice or because their resources are so in excess of the maximum threshold that their entitlement to social security (and its utility) is diminished. The vast majority of private spending on social security is on pensions and as such, this spending is accompanied by universal benefits. At present, these universal benefits are available irrespective of the financial capital of an individual. So, even for those happy to commodify their right to social security, there is still partial de-commodification through the basic state pension and other initiatives such as the winter fuel allowance. There may be qualitative repercussions for an individual being able to 'purchase' unemployment protection insurance or private pensions. However, social rights are only currently designed to impose modifications on the market rather than completely overhaul it (Marshall, [1950] 1992). If social rights were designed to do this, then any presence of private finance may compromise their substance. As it stands, private finance exists alongside a very large, publicly funded system of social security. Owing to their position in the labour market, recipients of social security state that they cannot afford private welfare insurance but that this has little bearing on their own lives because a publicly funded system of provision already exists (Dwyer, 2000: 107). It could be suggested then, that privately funded social security is only a problem for those willing to buy it.

A very small proportion of UK citizens entirely fund their own welfare (Burchardt and Propper, 1999). For those concerned about the qualitative implications of this, it would appear that this sort of behaviour and activity doesn't undermine collectivist principles. Those belonging to this 'private welfare class' have just as much support for universal benefits and public services as other citizens (Burchardt and Propper, 1999). Equally for users of public services, private finance in social security isn't necessarily deemed as problematic because on occasion it can enable citizens to maximise the social security available to them (Dwyer, 2000). Take-up and contribution to the (now defunct) Child Trust Fund can be seen as an example of this. Undoubtedly, private finance threatens the conceptual cogency of the right to social security: as it rearticulates a public social good as a private market commodity for some. This has challenged the rationalities of social security so that those with sufficient financial capital have been able to capitalise on increased social security expenditure. However, this is borne out more by the permeation of market principles in social security than a growth in private finance alone as illustrated below. 


\section{Social security privatisation: a means to whose end?}

Rising poverty and inequality are primarily explained by factors endogenous to social security privatisation (Joyce and Sibieta, 2013). Indeed as illustrated above, the institutional features of social security have proven largely resistant to welfare pluralism. Nevertheless, studies mapping the significance of privatisation tend to suggest that the resultant transformation of welfare services 'is of a qualitative, rather than quantitative nature' (Blomqvist, 2004: 151). The extent of social security privatisation has not changed dramatically overall since 1979 , but it would appear that a considerable shift has occurred in how we conceptualise the right to social security (Cox, 1998). Private provision, control and finance can be seen as an institutional expression of this trend. However, a 'privatisation ethos' has proven more pervasive in transforming the status and efficacy of social security provisions.

This 'privatisation ethos' has embedded market principles into ostensibly public social security arrangements. Many have argued that privatisation in social security means entitlements are reduced to any other form of property - a resource to be competed and bid for by both providers and recipients of social security (Dilley, 2000: 982). Whilst, this may be true in certain instances, this misrepresents the nature of welfare pluralism and the extent to which the existing income or capital of claimants has a bearing on social security entitlement and distribution. A more nuanced examination suggests that a 'privatisation ethos' is characterised by multiple factors that have a bearing on social security receipt. Factors typically affecting the allocation of market resources have become increasingly influential in shaping social security distribution. The existing income or capital of claimants is of course significant here, particularly in pension provision. However, other factors dominant in the market sphere such as knowledge, social capital and proficiency also have a bearing. In this sense, privatisation has had significant discursive repercussions on the right to social security whereby a 'competent citizen is the successful consumer, able to get the best out of services' (Dean, 2002: 18). Those equipped with the necessary knowledge of benefit regulations and the ability and resilience to negotiate administrative structures are best positioned to secure their social security entitlements. This is borne out in the changing distribution of social security. The permeation of market principles into welfare activity has affected the distribution of social security entitlements and payments such that resources are not being directed towards those most in need of them. Looking at three income groups across five time periods, it is apparent that social security provision has become notably less progressive in the (re-) distribution of financial resources since 1979 (see Table 2).

Table 2: Average proportion of gross income from direct cash benefits for three groups across the income distribution, 1979 to 2012

\begin{tabular}{lccc}
\hline & Bottom 20\% & Middle 20\% & Top 20\% \\
\hline $1979-80$ & $72.2 \%$ & $12.8 \%$ & $3.1 \%$ \\
$1995-96$ & $68.4 \%$ & $19.2 \%$ & $2.8 \%$ \\
$1999-00$ & $65.9 \%$ & $18.7 \%$ & $2.0 \%$ \\
$2007-08$ & $61.3 \%$ & $19.2 \%$ & $4.3 \%$ \\
$2011-12$ & $57.7 \%$ & $23.9 \%$ & $3.0 \%$ \\
\hline Source: ONS (2013), author's own analysis & &
\end{tabular}

Expressed as a share of gross income, the above table shows the average amount of direct cash benefits received by households at the bottom, middle and top of the income distribution. Existing literature suggests that the middle classes have been the 
biggest beneficiaries of public healthcare and education services (Matthews and Hastings, 2013). Table 2 shows that those in the middle of the income distribution have also been the biggest beneficiaries of increased social security expenditure since 1979. In 1979-80, those in the middle of the income distribution received on average 12.8 per cent of their gross income via direct cash benefits. By $2011-12$, this rose to 23.9 per cent. During the same period, the average share of gross income derived from direct cash benefits for those at the lower end of the income distribution fell from 72.2 to 57.7 per cent. Between 1979 and 2012, the income ratio between the 90th and 10th percentile of the income distribution rose from 3.1 to 3.9 , the income ratio between the 90th and 50th percentile rose from 1.7 to 2.0 and perhaps most significantly the income ratio between the 50th and 10th percentile rose from 1.8 to 1.9 (Crawford et al., 2013). In spite of considerable increases in expenditure, social security instruments have not only failed to reduce poverty and income inequality between the extreme ends of the income distribution, they have also failed to close the gap between the bottom and middle.

This trend in itself has not caused rising poverty and inequality, but it has done little to address such a phenomenon. To a great extent, the 'privatisation ethos' has left social security instruments less effectual in addressing inequalities arising from the market. The 'privatisation ethos' has shaped the utility and substance of social security; particularly for those most in need of it. Many have critiqued privatisation processes as problematic because they do not distribute resources according to need (Titmuss, 1968; Walker, 1984; Cox, 1998). This is quite evidently the case here but it is not so much the absence of a moral imperative to address need that explains the detrimental effect of privatisation. Rather, it is the presence of a more salient priority to introduce market principles into the public services sphere. The rise of consumer citizen identities (Clarke et al., 2005) has enabled those with the most financial and non-financial resources at their disposal to capitalise on social security provision. For example, middle income groups have disproportionately benefited from child benefit, disability living allowance and attendance allowance since 1979 (ONS, 2013). In nominal terms, middle income groups have consistently received a greater amount of these benefits compared to those at the lower end of the income distribution (ONS, 2013). The extent to which this group receives more has risen substantially since 1979 with factors such as knowledge, proficiency and resilience becoming increasingly significant in the stratification of public resources (Clarke et al., 2007).

Importantly, it is not only market factors that dictate the appropriation and distribution of social security according to vested interests. Political power has perhaps an equal, if not more profound, effect. Various studies have shown that those most able to wield political power over social policies and provision are the greatest beneficiaries of public services (Le Grand and Winter, 2000; Manow, 2009; Matthews and Hastings, 2013). Underlying consumer citizen practices then, the vested interests of the politically engaged electorate shape the extent and distribution of social security entitlements. Meltzer and Richard (1981: 924) argue that redistributive outcomes are greatly determined by the 'welfare maximising choice of decisive individuals'. Median voter theory suggests that rising inequality precipitates increased rates of redistribution via median voter preferences. However, the changing distribution of social security receipt has to some extent buffered the effects of rising inequality on median (and thus decisive) voters. Alongside this, hardening attitudes towards welfare (Park et al., 2012) and the rising identity of consumer citizens (Clarke et al., 2005) amplifies the 'privatisation ethos' and its effects. In its various permutations, Tax Credits can be seen as an example of this. In 1977, only those at the lower end of the income distribution were entitled to Family Credit: on average, the bottom 20 per cent of households received $£ 3$ a year in provisions. By 1986, this increased to an average of $£ 20$ a year, and $£ 103$ a year by $1995-96$. During the same period, entitlement extended to those 
in the middle of the income distribution with these households receiving on average $£ 5$ a year in 1986 and $£ 43$ a year in 1995-96. In an attempt to address rising poverty and inequality (attendant to other policy objectives), Tax Credits became an increasingly important feature of social security under New Labour. To sustain support for increased social security expenditure, Tax Credit entitlement extended drastically so that the material benefits of increased expenditure were manifest and justifiable to median voters (Dean, 2013). By 2011-12, households at the bottom (20 per cent) of the income distribution received $£ 1,253$ a year in Tax Credits on average, whilst households in the middle (20 per cent) of the income distribution received $£ 654$ a year on average.

Such developments have led to a system of social security provision that increasingly manages voters' wants rather than citizens' needs. The decoupling of social rights from civil and political rights compromises the share of social security received by those at the bottom end of the income distribution, whilst protecting (and indeed expanding) the social security entitlements of those in the middle (Barr, 2012). However much a market ethos is present in public services, legislative entitlement is the ultimate dictate of social security receipt. After all, claimants can only bid for goods if they are let into the auction house. Accordingly, caution should be taken not to overstate the extent to which privatisation trends have reduced the right to social security to any other form of property. As previously discussed, this would only reflect one extreme end of the welfare continuum. It would appear that a fulfilment of the right to social security is dictated not so much by fundamental needs, but by individual ability to exert consumer interests and democratic power in the public sphere. As a result, the logic of privatisation has fed into the structuring and administration of social security to undermine its utility. Not only is privatisation and the ethos informing it compromising the right to social security for those most in need of it; those least in need of it are actually benefiting from this process also.

\section{Conclusion}

Despite political rhetoric and will since 1979, shifts made towards privatisation have been gradual and the majority of social security activity remains publicly controlled, delivered and financed. Nevertheless, this paper has illustrated that both privatisation processes and the permeation of market principles into the public services sphere have weakened the capacity for social security to address rising poverty and inequality.

Control, delivery and finance all have a mutually contingent and reinforcing bearing on the right to social security. One has to explore how they interact to understand their respective and collective effects. In doing so, this paper has illustrated that privatisation has procedurally and thus substantively affected the right to social security. Market principles have come to feature in social security provisions that, ostensibly at least, remain public. The 'privatisation ethos' that has informed minor shifts in the regulation, provision, and funding of social security has also come to shape the increasingly regressive distribution of social security transfers. Not only has the efficacy of social security expenditure been compromised, but importantly the logic of privatisation has altered the nature and interpretation of the right to social security (Dean, 2002). The 'privatisation ethos' and its procedural and institutional manifestations increase the mandate of those with democratic influence and (non-) financial resources to maximise the social security they receive. In this sense, rather than guaranteeing a minimum income independent of the labour market to fulfil citizen needs, social security has increasingly come to supplement income based on labour market participation to maximise consumer citizen wants. 
The Conservative-Liberal Democrat coalition government concede that public services are often poorly targeted and inegalitarian (Cabinet Office, 2011). With a renewed commitment to opening up public services to market competition, it would appear that the distribution of social security is set to become increasingly regressive. Growth in social security spending may have tempered some of the negative effects since 1979, but fiscal austerity is set to further threaten the content, substance and justiciability of the right to social security.

\section{Notes}

1 Depending on the ethic of need assumed, social security can do anything from meet basic survival requirements to enable effective human flourishing (Dean, 2010).

\section{Acknowledgements}

This paper builds on work undertaken by Tania Burchardt, Rachel Smithies and John Hills at the Centre for the Analysis of Social Exclusion. Many thanks to the reviewers for their constructive feedback.

* Correspondence Address: Daniel Edmiston, School of Sociology and Social Policy, University of Leeds, LS2 9JT. Email: D.Edmiston@leeds.ac.uk

\section{References}

Banks, S. (2011) Ethics in an age of austerity: social work and the evolving new public management. Journal of Social Intervention: Theory and Practice, 20, 2, 5-23.

Barr, B. (2012) Stop blaming the unemployed and focus on the universal system of mutual security. British Medical Journal, 344, e537.

Beresford, P. and Croft, S. (1983) Welfare pluralism: the new face of fabianism. Critical Social Policy, 3, 9, 19-39.

Blomqvist, P. (2004) The Choice Revolution: Privatization of Swedish Welfare Services in the 1990s. Social Policy \& Administration, 38, 2, 139-155.

Brudney, J., Fernandez, S., Ryu, J.E. and Wright D. (2005) Exploring and explaining contracting out: patterns among the American States. Journal of Public Administration Research and Theory, 15, 3, 393-419.

Burchardt, T. (1997) Boundaries between public and private welfare: a typology and map of services. CASE report 2. London: LSE.

Burchardt, T. and Hills, J. (1997) Private welfare insurance and social security. JRF Social Policy Research Findings 111. York: Joseph Rowntree Foundation.

Burchardt, T. (2013) Re-visiting the conceptual framework for public/private boundaries in welfare. Social Policy in a Cold Climate Research Note Series 2. London: Centre for the Analysis of Social Exclusion, LSE.

Burchardt, T. and Propper, C. (1999) Does the UK have a private welfare class? Journal of Social Policy, 28, 4, 643-665.

Cabinet Office (2011) Open Public Services. London: HMSO.

CESI (2014) Work programme statistics: Inclusion analysis. London: Centre for Economic and Social Inclusion.

Clarke, J. (2004) Dissolving the public realm?: The logics and limits of neo-liberalism. Journal of Social Policy, 33, 1, 27-48. 
Clarke, J. and Newman, J. (1997) The Managerial State: Power, politics and ideology in the remaking of social welfare. London: Sage.

Clarke, J., Smith, N. and Vidler, E. (2005) Constructing Citizen-Consumers: inequalities and instabilities. In: M. Powell, K. Clarke and L. Bauld. Social Policy Review 17. Bristol: The Policy Press.

Clarke, J., Newman, J., Smith, N., Vilder, E. and Westmarland, L. (2007) Creating citizen-consumers: changing publics and changing public services. London: Sage.

Considine, M., Lewis, J. and O'Sullivan, S. (2011) Quasi-markets and service delivery flexibility following a decade of employment assistance reform in Australia. Journal of Social Policy, 40, 4, 811-833.

Coote, A. (ed.) (1992) The welfare of citizens: developing social rights. London: Institute for Public Policy Research.

Cox, R. (1998) The Consequences of welfare reform: How conceptions of social rights are changing. Journal of Social Policy, 26, 1, 1-16.

Crawford, R., Emmerson, C., Tetlowm G., Adam, S., Browne, J., Joyce, R., Phillips, D., Wenchao, J., Joyce, R., Sibieta, L. and Cribb, J. (2013) IFS Fiscal Facts and Incomes in the UK. London: Institute for Fiscal Studies.

Davies, S. (2008) Contracting out employment services to the third and private sectors: a critique. Critical Social Policy, 28, 2, 136-164.

Dean, H. (2002) Welfare Rights and Social Policy. Harlow: Prentice Hall.

Dean, H. (2010) Understanding human need. Bristol: Policy Press.

Dean, M. (2013) Democracy under attack: how the media distort policy and politics. Bristol: Policy Press.

Dilley, P. (2000) Taking public rights private: the rhetoric and reality of social security privatisation. Boston College Law Review, 41, 5, 975-1057.

Dorfman, A. and Harel, A. (2013) The case against privatisation. Philosophy and Public Affairs, 41, 1, 67-102.

DPAC. (2012) Working Capability Assessment - a survey of disabled people's experiences. London: DPAC.

Drakeford, M. and Campling, J. (2000) Privatisation and social policy. Harlow: Longman.

DWP (2013) The Annual Abstract of Statistics for Benefits, National Insurance Contributions, and Indices of Prices and Earnings. Sheffield: Department for Work and Pensions, Information, Governance and Security Directorate.

DWP (2014) Employment and Support Allowance: outcomes of Work Capability Assessments, Great Britain: Quarterly official statistics bulletin. Sheffield: Department for Work and Pensions, Information, Governance and Security Directorate.

Dwyer, P. (2000) Welfare Rights and Responsibilities: Contesting Social Citizenship. Bristol: Sage.

Edmiston, D. (2011) The shifting balance of private and public welfare activity in the UK, 1979 to 2007. CASE report 155. London: LSE.

Esping-Andersen, G. (1990) The three worlds of welfare capitalism. Cambridge: Polity Press.

European Union (2013) Your social security rights in the United Kingdom. Brussels: Employment Social Affairs and Inclusion, European Commission.

Franklin, L. (2013) How norms become targets: investigating the real reason for the misery of 'fit for work' assessments. Sheffield: Centre for Welfare Reform.

Gamble, A. (1992) The weakening of social democracy, In: M. Loney, R. Bocock, J. Clarke, Al. Cochrane, P. Graham and M. Wilson, The State of the Market. London: Sage.

Grover, C. (2009) Privatizing employment services in Britain. Critical Social Policy, 29, 3, 487-509. 
Hills, J. (2011) The changing architecture of the UK welfare state. Oxford Review of Economic Policy, 27, 4, 589-607.

Hutton, W. (2011) The State We're In. London: Random House.

Hyde, M., Dixon, J. and Drover, G. (2003) Welfare retrenchment or collective responsibility? The privatisation of public pensions in Western Europe. Social Policy and Society, 2, 3, 189-197.

Joyce, R. and Sibieta, L. (2013) An assessment of Labour's record on income inequality and poverty. Oxford Review of Economic Policy, 29, 1, 178-202.

Kathleen, L. (2006) Neo-liberalism and marketization: the implications for higher education. European Educational Research Journal, 5, 1, 1-17.

Lansley, S. (2014) Britain's wages crisis: is 'predistribution' or 'redistribution' the way forward? The Political Quarterly, 85, 1, 3-10.

Le Grand, J. and Robinson, R. (1984) Privatisation and the welfare state: an introduction, In: J. Le Grand and R. Robinson (eds.), Privatisation and the welfare state. London: Allen and Unwin.

Le Grand, J. and Winter, D. (2000) The middle classes and the welfare state under Labour and Conservative governments, In: R. E. Goodin and D. Mitchell, The Foundations of the Welfare State. Cheltenham: Edward Elgar.

Lister, R. (1998) New conceptions of citizenship, In: N. Ellison and C. Pierson, Developments in social policy. Basingstoke: Macmillian.

Manow, P. (2009) Electoral rules, class coalitions and welfare state regimes, or how to explain Esping-Andersen with Stein Rokkan. Socio-Economic Review, 7, 1, 101 121.

Marshall, T. H. (1950) Citizenship and Social Class. Reprinted in Marshall, T.H. and Bottomore, T. (1992). London: Pluto Press.

Matthews, P. and Hastings, A. (2013) Middle-class political activism and the middleclass advantage in relation to public services: a realist synthesis of the evidence base. Social Policy and Administration, 47, 1, 72-92.

Melden, A. (1979) Rights and Persons. Berkeley: University of California Press.

Meltzer, A. and Richard, S. (1981) A rational theory of the size of government. Journal of Political Economy, 89, 5, 914-927.

Murphy, J., Gilmer, S., Weise, R., and Page, A. (1998) Pathways to Privatisation in Education. Greenwich: Praeger.

NAO (2013) The role of major contractors in the delivery of public services. Government contracting HC810: Report by the Comptroller and Auditor General. London: The Stationery Office.

Netter, J. and Megginson, W. (2001) From state to market: a survey of empirical studies on privatisation. Journal of Economic Literature, 39, 2, 321-389.

Newton, B., Meager, N., Bertram, C., Corden, A., George, A., Lalani, M., Metcalf, H., Rolfe, H., Salisbury, R. and Weston, K. (2012) Work programme evaluation: findings from the first phase of qualitative research on programme delivery. Department for Work and Pensions Research Report 821, Sheffield: DWP.

ONS (2013) The effects of taxes and benefits on household income, 2011/12: income, tax and benefit data by income decile for all households. London: Office for National Statistics.

Papadakis E. and Taylor-Gooby, P. (1987) The provision of public welfare: State Market and Community. Brighton: Wheatsheaf.

Park, A., Clery, E., Curtice, J., Phillips, M. and Utting, D. (eds.) (2012) British Social Attitudes: the 29th Report. London: NatCen Social Research.

Pollock, A.M. (2006) NHS plc: The privatisation of our health care. London: Verso.

Powell, M. and Miller, R. (2014) Framing privatisation in the English National Health Services. Journal of Social Policy, available on CJ02014. doi:10.1017/S0047279414000269. 
Rees, J., Whitworth, A. and Carter, E. (2014) Support for all in the UK Work Programme? Differential Payments, Same Old Problem. Social Policy \& Administration, 48, 2, 221-239.

Self, P. (2000) Rolling back the market: economic dogma and political choice. London: Macmillan Press.

Shildrick, T., MacDonald, R., Webster, C. and Garthwaite, K. (2012) Poverty and Insecurity: Life in 'low-pay, no-pay' Britain. Bristol: Policy Press.

Smithies, R. (2005) Public and Private Welfare Activity in the UK, 1979 to 1999. CASE report 93, London: LSE.

Taylor-Gooby, P., Larsen, T. and Kananen, J. (2004) Mark Means and Welfare Ends: The UK Welfare State Experiment. Journal of Social Policy, 33, 4, 578-582.

Titmuss, R. M. (1968) Commitment to Welfare. London: Allen and Unwin.

Toebes, B. (2006) The Right to Health and the Privatization of National Health Systems: A Case Study of the Netherlands. Health and Human Rights, 9, 1, 102-127.

Torry, M. (2013) Money for everyone: why we need a citizen's income. Bristol: Policy Press.

Twine, F. (1994) Citizenship and Social Rights. London: Sage.

Walker, A. (1984) The political economy of privatisation, In: J. Le Grand and R. Robinson, Privatisation and the welfare state. London: Allen and Unwin.

Wood, G. (2004) Informal security regimes: the strength of relationships, In: I. Gough, and G. Wood, Insecurity and welfare regimes in Asia, Africa and Latin America: Social Policy in Development Contexts. Cambridge: CUP. 